Research Notes

\title{
Characterizing Soil Penetration Resistance of Planted Sago Palm (Metroxylon spp.) Under Mineral Soils Ecosystem
}

\author{
${ }^{1}$ Mohd Effendi Wasli, ${ }^{1}$ Nurul Hidayah Che Ali, ${ }^{2}$ Roland Yong, ${ }^{1,3}$ Mugunthan Perumal, ${ }^{1}$ Awang Ahmad \\ Sallehin Awang Husaini, ${ }^{1}$ Meekiong Kalu, ${ }^{1}$ Sim Siong Fong and, ${ }^{1}$ Aina Nadia Najwa Mohamad Jaffar \\ ${ }^{1}$ Faculty of Resource Science and Technology, Universiti Malaysia Sarawak, Malaysia \\ ${ }^{2}$ CRAUN Research Sdn Bhd, Malaysia \\ ${ }^{3}$ Institute of Ecosystem Science Borneo, Universiti Putra Malaysia (Bintulu Sarawak Campus), Malaysia
}

\author{
Article history \\ Received: 06-08-2021 \\ Revised: 26-09-2021 \\ Accepted: 16-10-2021 \\ Corresponding Author: \\ Mohd Effendi Wasli \\ Faculty of Resource Science and \\ Technology/Universiti Malaysia \\ Sarawak, Malaysia \\ Email: mohdeffendiw@gmail.com
}

\begin{abstract}
In-situ soil assessment such as field soil compaction can often be a helpful approach in help determining soil suitability for certain crops. In this study, an assessment was conducted to characterize the Soil Penetration Resistance (SPR) in planted sago palm (Metroxylon spp.) plantation at different growth of rosette and trunking stages under mineral soils ecosystem. SPR in-situ assessment would provide a beneficial guideline and site indicator in determining land suitability before establishing sago plantations, especially on mineral soils. The study was conducted in Mukah, Sarawak, with two study sites at Oya and Talau. The growth stage of sago palm at Oya and Talau site were at the rosette and trunking stage, respectively. The soil types at both study sites consisted of Gley soils (clayey) with significant mineral development at the subsoil horizon. SPR measurements were taken using a Hasegawa-type cone penetrometer. Soil compaction in SSSED Oya was more compact than Talau river research station from shallow depth to subsurface soils. SPR at SSSED Oya ranged between 7.5 to $46.8 \mathrm{~J} \mathrm{~cm}^{-1}$, while Talau river research station ranged between $1.9 \mathrm{~J} \mathrm{~cm}^{-}$ ${ }^{1}$ to $11.1 \mathrm{~J} \mathrm{~cm}^{-1}$. Although there was a significant difference between the growth stage of $0-20 \mathrm{~cm}$ and $80-100 \mathrm{~cm}$ soils depths, both SSSED Oya and Talau river research station are considered suitable areas for sago palm plantations. Using a practical and convenient approach in assessing soil suitability for sago cultivation, SPR assessment to identify potential areas for the establishment of sago cultivation area can be the fundamental tools for landowners in preparing their land for future cultivation.
\end{abstract}

Keywords: Soil Penetration Resistance, Metroxylon spp., Mineral Soil

\section{Introduction}

Sago palm (Metroxylon spp.) brings many economic and ecosystem services secondary to oil palm; thus, it has the potential to be a crop that deserves prompt attention. The sago palm industry in Sarawak has become one of the important industries contributing to export revenue for sago-related initiatives in Malaysia (Mohamad Naim et al., 2016; Bujang, 2018). Mainly, it was found in the wild, semi-wild, or cultivated by smallholders along the coastal belt, low-lying river areas of the region, including peat swamps. There are two types of sago palms commonly found in Sarawak: The smooth sheathed (Metroxylon sagu) and spiny sheathed (Metroxylon rumpii). According to Tie et al. (1991), the main areas of sago cultivation in Sarawak were mainly located at Oya-Dalat and Mukah region. Since 1992, the total area covered with sago palm in Sarawak has expanded due to the introduction of estate sago plantations by the Sarawak State Government (Karim et al., 2008). In achieving sustainable substantial 
yield production, good agriculture management practices must be done simultaneously from the land cleaning stages until harvesting stages (Omori et al., 2002; Pei-Lang et al., 2006; Jong, 2018).

However, very few studies are available on the management of smallholder farmers' practices in improving sago palm growth with increased starch yield (Khan, 2005; Yong, 2014). The excellent growth performance of crops must start with a suitable planting site, good planting materials and an effective planting system (Bujang, 2018). The challenges in cultivating sago palm in Sarawak on peat soils are the inability of the sago palm to develop trunk, long maturity period, low survival rate, slow growth performance, low starch yield and soil problem (Pei-Lang et al., 2006; Khan, 2005; Yong et al., 2018). Due to these characteristics, peat swamp is unfavorable for the use of sago palm cultivation due to fewer fertilizers and pesticides being applied (Bujang, 2018).

Several reports discuss the influence of various soil properties in sago palm growth development and production when cultivated under smallholder or commercial scale plantations (Bintoro et al. 2018; Okazaki and Sasaki, 2018; Nelsi et al., 2021; Uthumporn et al., 2014; Yong et al., 2018). While in-situ soil assessment such as field soil compaction and other soil physical attributes are often found to be a helpful approach in determining soil suitability for certain crops, information on characterizing the state of soil compactness, especially in sago plantation, is still scarce.

Soil physical properties play a vital role in the growth of plants. Improving the soil fertility of agricultural lands can be done even for a shorter period by adopting various technologies, such as adding amendments, i.e., organic and chemical fertilizers. However, this may not be the case when dealing with limitations due to soil physical properties since improving soil physical properties requires more effort and investment (Sakurai et al., 1995). Conventionally, a soil pit will be dug at specific points within a land area when soil physical properties are to be assessed. This allows the field assessor to assess certain soil depth; in most cases, digging soil pits within a land area may cause certain forms of disturbance, especially in land areas that consist of standing vegetation or crops. To properly study the effects of these properties, it is necessary to establish a method that can estimate the soil structure quantitatively with minimal disturbance to the actual soil structure that leads to a more practical diagnosis of the soil condition in the field (Mohamad Jaffar et al., 2018).
Considering the statement above, this research note was conducted to characterize the Soil Penetration Resistance (SPR) in planted sago palm at different growth of rosette and trunking stages under mineral soils ecosystem. SPR in-situ assessment would provide a beneficial guideline and site indicator in determining land suitability before establishing sago plantations, especially on mineral soils.

\section{Materials and Methods}

\section{Study Area}

This study was conducted at the Sago Smallholder Satellite Estate Development (SSSED) Plantation located at Mukah Division, Sarawak. Two study areas were selected for this study, namely, SSSED Oya (N02052'06.9" E111053'49.2") and Talau River Research Station (N02048'59.0" E111054'22.4”) as shown in Fig. 1.

The soil types in SSSED Oya and Talau research station consist of Gley soils (clayey). The assessment and sampling were selected based on two different growth stages of sago palm under mineral soils.

Two growth stages of sago palm were selected: Rosette stage (one-year-old) and trunking stage (more than five years old). At SSSED Oya, the sago palm is in the rosette stage, while the Talau River research station is at the trunking stage. In general, land preparation for sago palm plantations included land clearing and bush slashing. Each sago palm was planted in a triangular system with a spacing of $7 \times 10 \mathrm{~m}$.

\section{Soil Penetration Resistance Evaluation}

A Hasegawa-type penetrometer (Daito Techno Green Co., Tokyo, H-60) was used to estimate soil compaction from surface soils to $100 \mathrm{~cm}$ depth. The soil compaction at different soil depths was expressed in One Drop Penetrability (ODP), as shown in Fig. 2. The horizontal axis shows the penetrating depth $(\mathrm{cm})$ per one drop of weighing; meanwhile, the vertical axis represents the cumulative depth (cm) (Mohamad Jaffar et al., 2018). The degree of soil compaction was classified using the value plotted on the horizontal axis following Sakurai et al. (1995).

The Soil Penetration Resistance (SPR) was evaluated using Hasegawa type-cone penetrometer. The soil depth range for each assessment was at a depth of $100 \mathrm{~cm}$. The total number of strikes was counted to $20 \mathrm{~cm}$ interval depth and SPR was calculated using the following formula:

$$
E=M \times G \times H \times C
$$


where, $E$ is the soil penetration resistance $(J), M$ is the mass of the penetrometer $(2.0 \mathrm{~kg}), G$ is the gravitational acceleration $(9.8 \mathrm{~m} \mathrm{~s}-2), H$ is the vertical drop of the penetrometer weight $(0.5 \mathrm{~m})$ and $C$ is the count of strikes for each depth (Sakurai et al., 1995; Hattori et al., 2013; Mohamad Jaffar et al., 2018). The data on SPR were statistically analyzed using a Student t-test to compare the significant difference between the different growth stages. The statistical test was performed using SPSS version 17.0 for Windows.

\section{Agronomic Practices in the Sago Plantation}

The standard agronomy procedures and practices for sago palm under mineral soils were established by CRAUN research as a guideline for farmers. The selection of planting material is a part of agronomic practices. In sago plantations under SSSED, only planting materials that had achieved all standard criteria will be used for field planting. Commonly, sago palm underwent 5 to 7 months of hardening period, the height of 60 to $76 \mathrm{~cm}$, having more than six healthy fronds, base girth diameter of more than $6 \mathrm{~cm}$, green frond and dark red spear of not more than $30 \mathrm{~cm}$ height (Yusup et al., 2007).

Agronomic practices included in sago palm maintenance were weed control, cluster maintenance, manuring and pest management. Weed control is done within each plot by slashing followed by a chemical spray of contact herbicides three times annually. The activities included in cluster maintenance were removing creepers and weeds within the cluster, pruning the dead or damaged fronds and sucker. As for manuring, the types of fertilizer applied for sago palm at present were straight and compound fertilizer. Types of straight fertilizers used were Urea $(46 \% \mathrm{~N})$, Rock Phosphate (37\% P) and Muriate of Potash (63\% K).

Meanwhile, the compound fertilizer used is N-P-K 12-12-17. Fertilizers were applied via broadcasting surrounding the palm, mainly at the root zone. The rate, frequency and types of fertilizer involved were systematically arranged following the standard practice in sago palm plantations (Yusup et al., 2007).

For pest management, sago palms were monitored monthly and control measures were taken if a severe outbreak occurred. Although pest and disease issues are relatively uncommon for sago palm cultivation, the increased cultivation intensity has likely posed a danger for such attacks. Gumbek and Jong (1991) reported that few pests had been identified within the sago palm plantation area in Sarawak, namely Hispid beetles (Botronyopa grandis), termites (Captotermes spp.) and Red striped palm weevil (Rhynchophorus spp.).

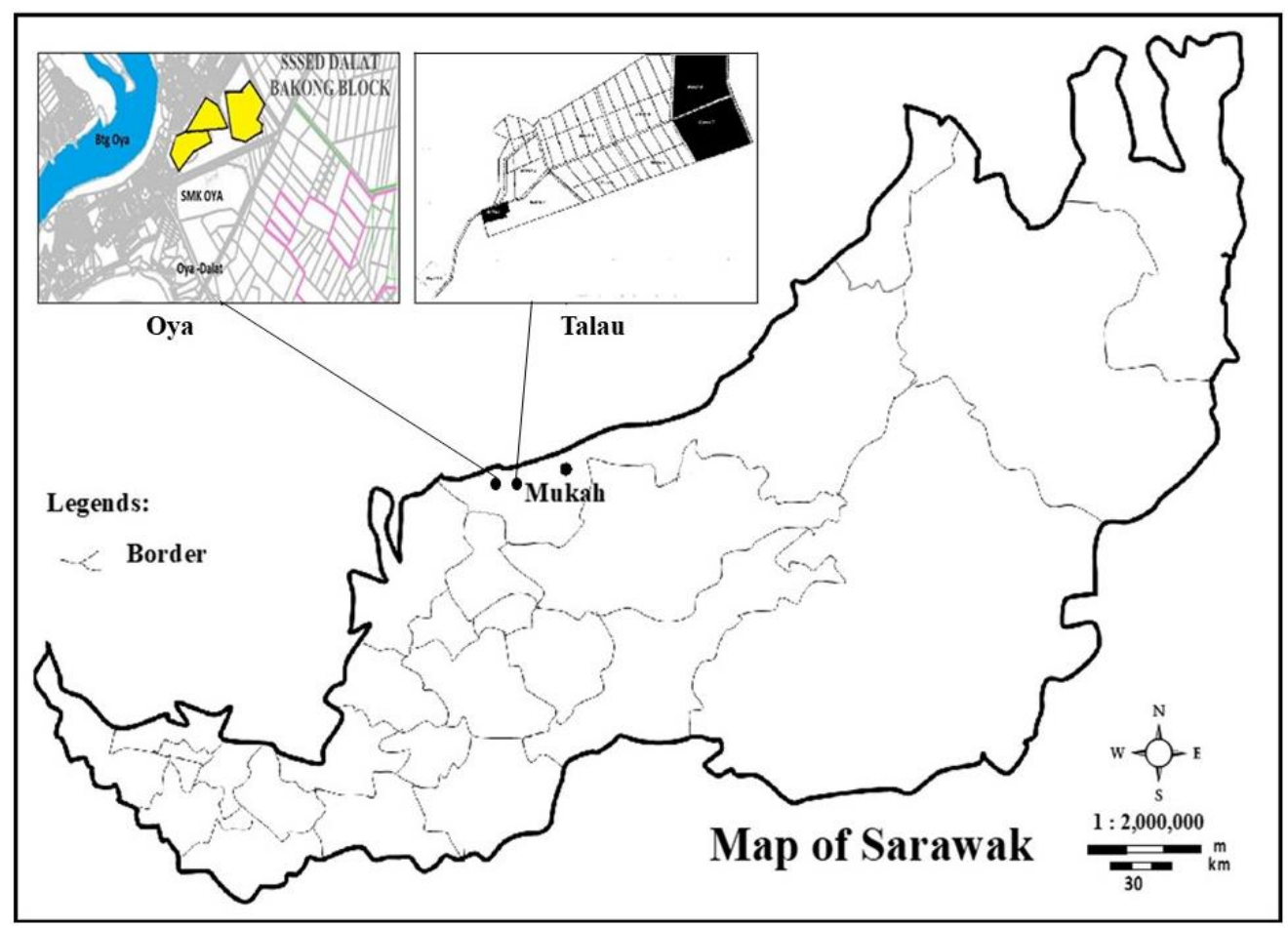

Fig. 1: Map of the study area 


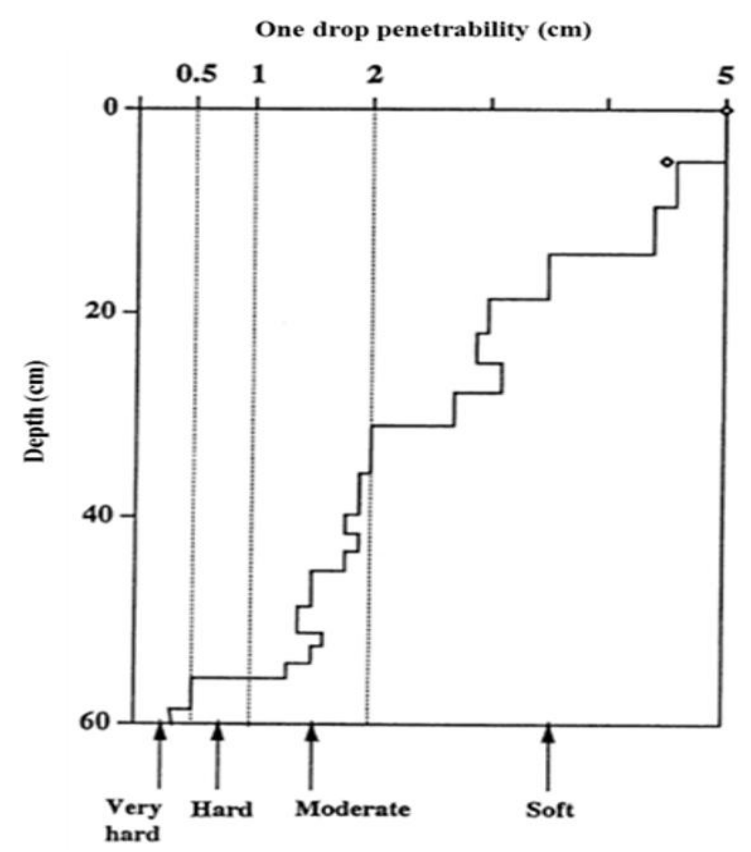

Fig. 2: One drop penetrability (ODP) and definition of soil hardness (Mohamad Jaffar et al., 2018; Sakurai et al., 1995)

\section{Results and Discussion}

\section{Soil Penetration Resistance (SPR)}

Soil compaction is a significant determinant of plants' plant growth and mortality rates (Hattori et al., 2013). Furthermore, it can provide a fundamental component that indicates land degradation as it reflects the productivity of the land areas (Iwasaki et al., 2020). Overuse of heavy machinery, intensive cropping, short crop rotations, intensive grazing and inappropriate soil management will lead to compaction (Adnan et al., 2017). Figure 3 indicates the soil ODP for both study sites. The results showed that the soil compaction in Talau River was categorized as soft soil from $0-45 \mathrm{~cm}$ depth, while soils from 45-100 cm depth were classified as moderate. It was noted that based on our field observation, the presence of peat soil at the soil surface with alluvial soil formed at subsoil layers with well-drained conditions. On the other hand, soil compaction for the site at Oya indicated that soil compaction was categorized as hard to very hard, starting from $25 \mathrm{~cm}$ and below.

Based on Fig. 4, there was a significant difference between planting stages at $0-20 \mathrm{~cm}$ and $80-100 \mathrm{~cm}$ soil depths. The highest average of compaction was shown on the rosette stage at $60-80 \mathrm{~cm}$ soil depth with $46.8 \mathrm{~J} \mathrm{~cm}^{-1}$, followed by $40-60 \mathrm{~cm}$ soil depth with $24.2 \mathrm{~J} \mathrm{~cm}^{-1}$ and $20-40$ $\mathrm{cm}$ soil depth with $15.0 \mathrm{~J} \mathrm{~cm}^{-1}$. For both study areas between $20-80 \mathrm{~cm}$, there was no significant difference between the growth stage of rosette and trunking.

High compaction up to $80 \mathrm{~cm}$ soil depth probably occurs due to heavy machinery during the land preparation at the initial establishment of study plots. In addition, the water table in study areas may likely affect the soils and palm growth. The water table height for palm trees was varied in which the atmospheric and water pressure influenced the grounded level of soils. At the trunking stage, SPR for soil depth $80-100 \mathrm{~cm}$ was $2.0 \mathrm{~J} \mathrm{~cm}^{-1}$ which is less than the value of the rosette stage with $10.5 \mathrm{~J}$ $\mathrm{cm}^{-1}$. The factor that resulted in low SPR on the trunking stage may be the soil's physical properties in the study area.

SPR at trunking stage at $20-40 \mathrm{~cm}$ and $40-60 \mathrm{~cm}$ soil depths was $4.9 \mathrm{~J} \mathrm{~cm}^{-1}$ and $8.2 \mathrm{~J} \mathrm{~cm}^{-1}$, respectively. The study site of the trunking stage consists of a waterlogged condition and its influence on SPR reading. The ideal layer of mineral soils condition allows the palms' anchorage on trunking and reduces the time consumed by the palm in developing the runners on the ground. In addition, optimum soil compaction allows for more efficient uptake of water and nutrients for the crop of the vacant layer. Thus, the application of soluble forms of fertilizers such as Nitrogen $(\mathrm{N})$, Phosphorus $(\mathrm{P})$ and Potassium $(\mathrm{K})$ was readily available for the requirements of palm trees under mineral soils. The optimum level of soil compaction might help reduce fertilizer losses such as surface runoff and leaching if the loose grounds were available.

Sago palm under will develop large and medium roots predominated at deeper soil layers. For sago cultivation in deep peat soil, such conditions to the root system might cause oxygen deficiency which would be expected to be severe in the deeper part of the soil depth (Miyazaki et al., 2011). However, this may not be the case as observed in the Talau River site as although the soils are high in moisture, especially in the surface soil, the deeper part of the soils were consists of mainly clayey-textured mineral soils. For the case of Oya sites, the deeper soil layers were mostly compacted even at a depth of $30 \mathrm{~cm}$ (Fig. 3), leading to a decrease in porosity, which is often associated with obstructive drainage with a high bulk density.

\section{In-Situ Observation of Sago Palm Plantation Under Different Growth Stages}

Based on field observation and sago palm physical indicator standard of previous studies done by Yong (2014), the growth performance of sago palm was summarized in Table 1.

The growth performance indicators were based on observing a number of fronds and the stage of the palm. The indication of poor fronds development is frond count less than 10, which means the sago palm fails to develop a sufficient number of fronds to be categorized as a "healthy" palm. Poor frond development of sago palm can be influenced by soil fertility, nutrient deficiency, disease and pest infestation. Based on in-situ observation, sago palm at SSSED Oya has moderate sago growth because 
frond counts of sago palm are between 10-15 and base girth diameter of sago palm more than $6 \mathrm{~cm}$. On the other hand, sago palm at Talau river research station was at the trunking stage with frond count of more than 15 .

Figure 5 illustrates the sago palm in the study areas at SSSED Oya and Talau river research station. According to Flach (1983), the maturity stages of healthy sago palm after flowering planted in peat soils are 10-14 years and 8-11 years under mineral soils ecosystem, respectively.

There are few possible factors lead to affect the performance of palm growth.

Ambak (2000) reported that over-draining causes the rapid decline and drying out of the soils layers, adversely affecting the development of the sago palms. Thus, the optimum water table should be determined and maintained by reducing the water flow rate between $20-40 \mathrm{~cm}$ from the soil surface (Ambak (2000). Besides, bushes and creepers should be slashed to a point no higher than palm trees to avoid the competition between planted and pioneer trees. Tree stumps and logs in abundance at study sites need to be removed because compacted soil continues to shrink the grounds.

Nozaki et al. (2004) reported that starch concentration was lower in sago palms grown under problematic soils are often susceptible to utilize storage compounds in order to overcome such adverse circumstances; however, this may not be the case for sago palm cultivated under mineral soil. Meanwhile, the root system of sago palm cultivated under peat soils was less developed than that on mineral soils (Miyazaki et al., 2011). The differences in growth of sago palm might be attributed to the lower soil fertility as the soil nutrient contents in the deeper soil layers of mineral soils were lower than those in the upper layers (Perumal et al., 2017; Ho et al., 2019). Moreover, soil compaction at subsoil may cause inhibition of the root development into the deeper layers of the soil where soil pore space is largely restricted.

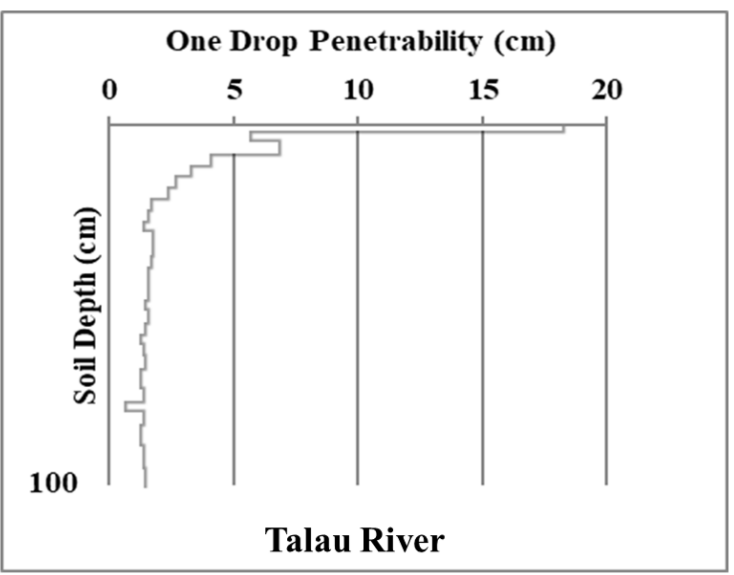

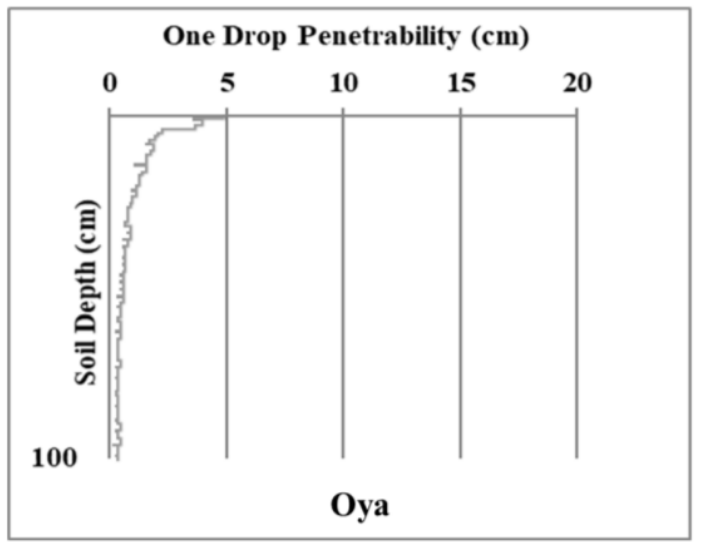

Fig. 3: One Drop Penetrability (ODP) in both study sites from $0-100 \mathrm{~cm}$ depth

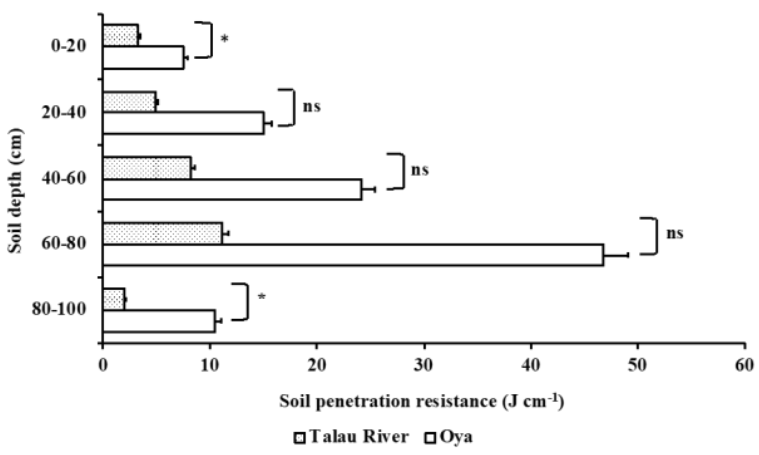

Fig. 4: Soil Penetration Resistance (SPR) in both sites; *in the same depths means significant differences at $5 \%$ using Student t-test; ns means no significant differences
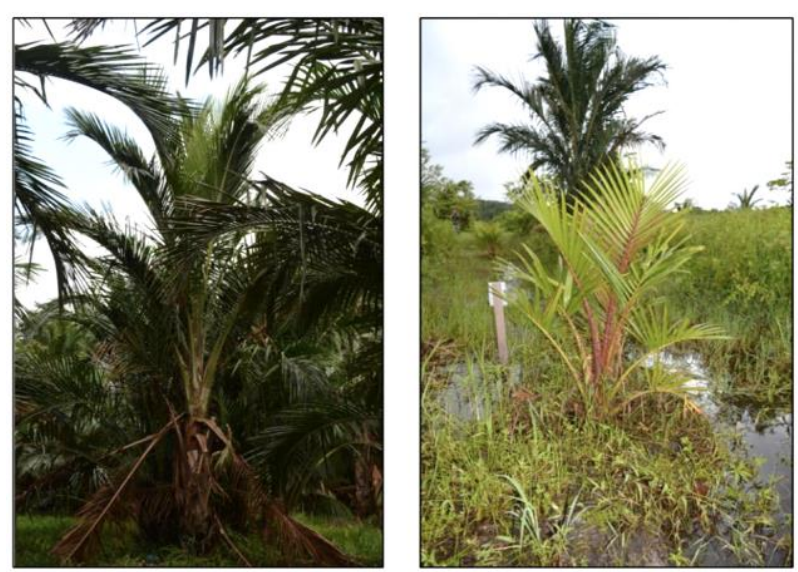

Fig. 5: Trunking stage at Talau river research station (left) and rosette stage at SSSED Oya (right)

Table 1: Summary of sago palm growth status (Yong, 2014)

\begin{tabular}{llll}
\hline Study area & Growth stage & Palm age & Frond count \\
\hline SSSED Oya & Rosette & 1 year old & $10-15$ \\
Talau river & Trunking & More than & More than \\
research station & & 5years old & 15 \\
\hline
\end{tabular}




\section{Conclusion}

This preliminary study concludes that soil compaction in SSSED Oya was more compacted than Talau river research station at shallow depth $(0-20 \mathrm{~cm})$ and subsurface soils $(80-100 \mathrm{~cm})$. There was no significant difference between the two planting stages of $20-40 \mathrm{~cm}, 40-60 \mathrm{~cm}$ and $60-80 \mathrm{~cm}$ soil depths. Based on SPR assessment, soils at SSSED Oya can support the growth performance of sago palm, although soil compaction in SSSED Oya was higher than in Talau River. Using a practical and convenient approach in assessing soil suitability for sago cultivation, SPR assessment to identify potential areas for the establishment of sago cultivation area can be the fundamental tools for landowners in preparing their land for future cultivation. It is noteworthy that further investigation in linking SPR attributes with other soil variables at temporal changes or growth stages in promoting better growth and yield production of sago palm should be considered. Such study will assist in developing proper agriculture management practices that cover the appropriate understanding of the soilplant relationship in sago cultivation. Furthermore, this specific approach for early prediction of land suitability before sago palm cultivation may apply to particular soil conditions. Further field trials and assessments are essential to determine the applicability of SPR as a suitable parameter for land suitability sago cultivation under mineral soil.

\section{Acknowledgment}

This research was financially supported by Tun Open Chair, Universiti Malaysia Sarawak. The authors wish to express gratitude to CRAUN Research Centre, especially to Mdm. Fariza Zaini and Mr. Peter Stanley Howell for their supportive assistance during the duration of this study.

\section{Funding Information}

Tun Openg Chair, Universiti Malaysia Sarawak (F07(ORC22)/1228/2015(09).

\section{Author's Contributions}

Mohd Effendi Wasli: Project leader of the research. Contributed in fieldwork, data analysis and preparation of manuscript.

Nurul Hidayah Che Ali: Researcher contributed in fieldwork and data analysis.

Roland Yong: Project member and contributed in experimental design, field sampling and data analysis.

Awang Ahmad Sallehin and Awang Hussaini: Coresearcher of the research project and provide considerable contribution on research idea.
Meekiong Kalu: Researcher contributed in drafting and reviewing the manuscript as well as data analysis.

Sim Siong Fong: Co-researcher of the research project and provide constructive suggestion for the manuscript.

Aina Nadia Najwa Mohamad Jaffar: Researcher contributed in drafting and reviewing the manuscript as well as data analysis.

Mugunthan Perumal: Researcher contributed in field assessment, data analysis and draft of the manuscript.

\section{Ethics}

The authors declare that there are no conflicts of interest regarding this paper publication.

\section{References}

Adnan, N. S, Tanveer, M., Shahzad, B., Yang, G., Fahad, S., Ali, S., Bukhari, M.A., Tung, M.A., Hafeez, A., \& Souliyanonh, B. (2017). Soil compaction effects on soil health and crop productivity: an overview. Environmental Science and Pollution Research, 24, 10056-10067. doi.org/10.1007/s11356-017-8421-y

Ambak, K. (2000). Management practices for sustainable cultivation of crop plants on tropical peatland. In Proceedings of the International Symposium on TROPICAL PEATLANDS, Bogor, Indonesia, 22-23 november 1999. https://ci.nii.ac.jp/naid/10020131299/

Bintoro, M. H., Nurulhaq, M. I., Pratama, A. J., Ahmad, F., \& Ayulia, L. (2018). Growing area of sago palm and its environment. In Sago Palm (pp. 17-29). Springer, Singapore.

ISBN: 978-981-10-5268-2

Bujang, K. (2018). Production, purification, and health benefits of sago sugar. In Sago Palm (pp. 299-307). Springer, Singapore. ISBN: 978-981-10-5268-2

Flach, M. (1983). The sago palm. Rome: FAO. https://www.bioversityinternational.org/fileadmin/us er_upload/online_library/publications/pdfs/238.pdf

Gumbek, M., \& Jong, F. S. (1991). Pests of Sago Palms in Sarawak. Towards Greater Advancement of the Sago Industry in the 1990s. Proceeding of 4th International Sago Symposium, August 6-9, 1990, Kuching, Sarawak, Malaysia, pp, 142-145.

Hattori, D., Kenzo, T., Kendawang, J. J., Ninomiya, I., \& Sakurai, K. (2013). Rehabilitation of degraded tropical rainforest using Dipterocarp trees in Sarawak, Malaysia. International Journal of Forestry Research, 2013. pp, 11. doi.org/10.1155/2013/683017 
Ho, S. Y., Wasli, M. E. B., \& Perumal, M. (2019). Evaluation of physicochemical properties of sandy-textured soils under smallholder agricultural land use practices in Sarawak, East Malaysia. Applied and Environmental Soil Science, 2019. doi.org/10.1155/2019/7685451

Iwasaki, K., Tamura, M., Sato, H., Masaka, K., Oka, D., Yamakawa, Y., \& Kosugi, K. I. (2020). Application of Ground-Penetrating Radar and a Combined Penetrometer-Moisture Probe for Evaluating Spatial Distribution of Soil Moisture and Soil Hardness in Coastal and Inland Windbreaks. Geosciences, 10(6), 238. doi.org/10.3390/geosciences 10060238

Jong, F. S. (2018). An overview of sago industry development, 1980s-2015. Sago palm, 75-89. ISBN-10: 978-981-10-5268-2

Karim, A. A., Tie, A. P. L., Manan, D. M. A., \& Zaidul, I. S. M. (2008). Starch from the sago (Metroxylon sagu) palm tree-properties, prospects, and challenges as a new industrial source for food and other uses. Comprehensive Reviews in Food Science and Food Safety, 7(3), 215-228. doi.org/10.1111/j.1541-4337.2008.00042.x

Khan, A. J., (2005). An examination of the correlation between peat soil characteristics and the growth of sago palm (Metroxylon sagu). (Unpublished master's thesis). Universiti Malaysia Sarawak, Sarawak, Malaysia.

Miyazaki, A., Yoshia, T., Yamamoto, Y., Chinen, Y., Rembon, F. S., Pasolon, Y. B., \& Jong, F.S., (2011). Effect of plant aging on root development of sago palm (Metroxylon sagu Rottb.) grown in Tebing Tinggi Island, Riau Province and in Kendari, Southeast Sulawesi in Indonesia. Tropical Agricultural Development, 55(3), 103-107

Mohamad Jaffar, A. N. N., Wasli, M. E., Perumal, M., Lat, J., \& Sani, H. (2018). Effects of soil compaction and relative light intensity on survival and growth performance of planted Shorea macrophylla (de Vriese) in riparian forest along Kayan Ulu River, Sarawak, Malaysia. International Journal of Forestry Research, 2018. doi.org/10.1155/2018/6329295

Mohamad Naim, H., Yaakub, A. N., \& Awang Hamdan, D. A. (2016). Commercialization of sago through estate plantation scheme in Sarawak: The way forward. International Journal of Agronomy, 2016. doi.org/10.1155/2016/8319542

Nelsi, O., Arsyad, U., Bachtiar, B., \& Rampisela, D. A. (2021, July). Soil properties and infiltration rate in sago palm (Metroxylon sago) forest in Rongkong Watershed South Sulawesi. In IOP Conference Series: Earth and Environmental Science (Vol. 807, No. 3, p. 032053). IOP Publishing. doi.org/10.1088/1755-1315/807/3/032053
Nozaki, K., Nuyim, T., Shinano, T., Hamada, S., Ito, H., Matsui, H., \& Osaki, M. (2004). Starch properties of the sago palm (Metroxylon sagu Rottb.) in different soils. Plant foods for human nutrition, 59(3), 85-92.

Okazaki, M., \& Sasaki, Y. (2018). Soil environment in sago palm forest. In Sago Palm (pp. 193-206). Springer, Singapore.

ISBN-10: 978-981-10-5268-2

Omori, K., Yamamoto, Y., Jong, F. S., Wenston, T., Miyazaki, A., \& Yoshida, T. (2002). Changes in Some Characteristics of Sago Palm Sucker Growth in Water and After Transplanting. In: New Frontiers of Sago Palm Studies, Kainuma K., et al. (Eds). The International Symposium on Sago, pp, 265-269.

Pei-Lang, A. T., Mohamed, A. M. D., \& Karim, A. A. (2006). Sago starch and composition of associated components in palms of different growth stages. Carbohydrate polymers, 63(2), 283-286. doi.org/10.1016/j.carbpol.2005.08.061

Perumal, M., Wasli, M. E., Ying, H. S., Lat, J., \& Sani, H. (2017). Association between soil fertility and growth performance of planted Shorea macrophylla (de Vriese) after enrichment planting at rehabilitation sites of Sampadi Forest Reserve, Sarawak, Malaysia. International Journal of Forestry Research, 2017. doi.org/10.1155/2017/6721354

Sakurai, K., Puriyakorn, B., Preechapanya, P., Tanpibal, V., Muangnil, K., \& Prachaiyo, B. (1995). Improvement of biological productivity in degraded lands in Thailand III: Soil hardness measurement in the field. Tropics, 4, 151-172. doi.org/10.3759/tropics.4.151

Tie, Y. L., Loi, K. S., \& Lim, K. E. T. (1991). The geographical distribution of sago (Metroxylon spp.) and the dominant sago-growing soils in Sarawak [Malaysia]. In 4. International Sago Symposium, Kuching, Sarawak (Malaysia), 6-9 Aug 1990. Ministry of Agriculture and Community Development.

Uthumporn, U., Wahidah, N., \& Karim, A. A. (2014, August). Physicochemical properties of starch from sago (Metroxylon Sagu) palm grown in mineral soil at different growth stages. In IOP Conference Series: Materials Science and Engineering (Vol. 62, No. 1, p. 012026). IOP Publishing. doi.org/10.1088/1757-899X/62/1/012026

Yong, R. Y. C. (2014). Soil edaphic condition in peat affecting the growth performance of sago palm. (Unpublished master's thesis). Universiti Malaysia Sarawak, Sarawak, Malaysia. 
Mohd Effendi Wasli et al. / OnLine Journal of Biological Sciences 2021, 21 (4): 338.345 DOI: 10.3844/ojbssp.2021.338.345

Yong, R. Y. C., Sobeng, Y., Zaini, F., \& Busri, N. (2018). Suitability of peat swamp areas for commercial production of sago palms: The Sarawak experience. In: Sago Palm-Multiple Contributions to Food Security and Sustainable Livelihoods, Ehara, H., Toyoda, Y. and D.V. Johnson (Eds.), Springer Nature, Singapore, pp, 75-90. ISBN-10: 978-981-10-5268-2
Yusup, S., Edwin, L. C. L., Noraini, B., \& Ahmad Zaki, H. (2007). Manual for planting and maintenance of sago plantation on peat. CRAUN Research Sdn. Bhd, Sarawak. 